\title{
PRODUCT ELIMINATION IN GERMAN INDUSTRIAL COMPANIES: A COMPARISON STUDY WITH US AND UK INDUSTRIAL COMPANIES
}

\author{
Christina Bauer ${ }^{1}$, Jana Turčínková1 \\ ${ }^{1}$ Department of Marketing and Trade, Faculty of Business and Economics, Mendel University in Brno, \\ Zemědělská 1, 61300 Brno, Czech Republic
}

Link to this article: https://doi.org/10.11118/actaun202068030585

Received: 11. 9. 2019, Accepted: 26. 5. 2020

To cite this article: BAUER CHRISTINA, TURČÍNKOVÁ JANA. 2020. Product Elimination in German Industrial Companies: A Comparison Study with US and UK Industrial Companies. Acta Universitatis Agriculturae et Silviculturae Mendelianae Brunensis, 68(3): 585-596.

\begin{abstract}
This paper focuses on the product elimination in German industrial companies, especially in the mechanical engineering sector. The Product Life Cycle (PLC) theory is based on the typical curve, which shows the different stages a product experiences over the time. The last stage, the so-called decline or elimination phase, is characterized with decreasing sales figures, low market share and shrinking profits. Therefore, it sounds logical that such products should be eliminated. This study is analyzing if these indicators really are the only reasons to start the elimination process of a product, or if there are other reasons triggering this decision too. This paper is based on results of personal structured interviews $(\mathrm{n}=102)$ with representatives of German mechanical engineering companies. The data was processed with use of statistical software SPSS, mean values and standard deviations were calculated, and Spearman's rank order correlation value analysis was applied. The results of this study were then compared with other earlier studies: Avlonitis (1984), Hart (1988), and Mitchell et al. (1998). The main findings suggest that the data from the new German study are highly correlating with the data from the United States (Mitchell et al., 1998) and the United Kingdom (Avlonitis, 1984; Hart, 1988). The results show that the reasons to phase out a product have not changed over the time; neither are the reasons different in different economics.
\end{abstract}

Keywords: product elimination, product deletion, product phase out, product life cycle, product management, engineering companies, Germany

\section{INTRODUCTION}

The reason for this study is to provide findings from research focused on a process of product elimination in German mechanical engineering companies. It aims to provide answers to questions: Which reasons trigger the decision to eliminate a product? Is the decision only based on shrinking sales values and profit figures?

According to Meffert et al. (2008) the products of a company are always in competition to each other. The products are competing against scarce resources like production capacity, marketing budget or financial budget. It is necessary to make objective-based decisions. They can be based on external factors like shortage of raw material or technology developments as well as internal factors like profit or company image.

One of the oldest economic models is the product life cycle concepts (Fischer, 2001) which describes the various phases a product experiences. Fisher (2001) connects the origin of the product life concept to Dean and Patton, both practitioner in the 1950's. Fisher (2001) states that Patton defines the PLC as time reference, systematic development of 


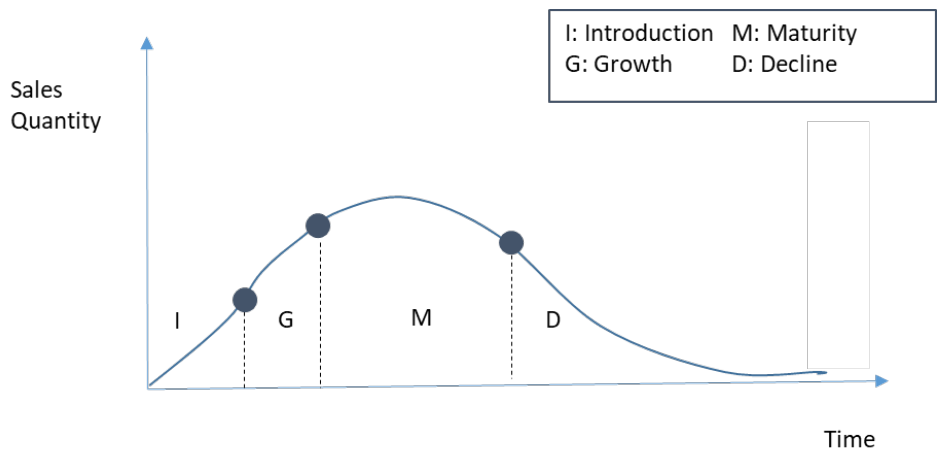

1: Product Life Cycle.

Source: Schmalen (2013)

I: PLC Models

\begin{tabular}{cc}
\hline $\begin{array}{c}\text { Four-phase model } \\
\text { (e.g. Ayal, 1981) }\end{array}$ & $\begin{array}{c}\text { Five-phase model } \\
\text { (e.g. Komninos } \text { et al., 2002) }\end{array}$ \\
\hline 1. Introduction & 1. Introduction \\
2. Growth & 2. Growth \\
3. Maturity & 3. Maturity \\
4. Decline & 4. Saturation \\
\hline
\end{tabular}

products based on the evolution of living creatures. The PLC has a critical characteristic, it is a dynamic consideration of a product and not an analysis of a specific situation (Kuss et al., 2007).

"The term 'lifecycle' generally indicates the whole set of phases, which could be recognised as independent stages to be passed/followed/performed by a product" (Terzi et al., 2010, p. 364). In the literature different models can be found, some of them divide the PLC in four, others are using a model with five phases.

No matter which model will be used it always describes a product by sold volume and revenues over the time (Terzi et al., 2010).

Marketing literature (e.g. Meffert et al., 2008; Kuss et al., 2007; Lennertz, 2006) is describing the dynamic of the PLC as typically, after successful development and testing, the product is launched into the market (introduction). At this stage special promotion and marketing activities support the growing sales. If the product experiences increasing sales figures, it enters the growth phase. At a certain point of time the sales volume stabilizes which indicates that the product entered the third phase, the so-called maturity. If the sales figures decrease for a certain longer period of time the product enters the decline phase and may need to be eliminated from the product portfolio. The length of each stage depends very much on the profit situation. A product will be offered longer to the market if the production costs are low and the demand is high, as this will lead to high revenues. If the production costs are high and the demand is low, it can be expected that the product will have a short product life.
In general, the marketing literature much more focuses on the product launch/product introduction phase and not so much on the deletion phase (Herrmann et al., 2000). "New products tend to have 'glamour' while the deletion of existing products is often regarded as 'drab business' as a firm wrestles with those products that have served it well over time" (Mitchell et al., 1998, p. 9).

Only a few researchers (e.g. Avlonitis, 1984; Hart, 1988; Mitchell et al., 1998) have focused their work on the decline stage. Hart (1988) as well as Avlonitis (1984) analyzed in different studies in the 1980's that not all weakly performing products are ready for elimination, nor were elimination candidates. Only those items with low profitability and declining sales (Mitchell et al., 1998). Avlonitis (1984) and Hart (1988) analyzed the British manufacturing companies, whereas Mitchell et al. (1998) focused their study on American manufacturing firms to compare their results with the ones of Avlonitis and Hart.

But not only in the literature the last phase is treated neglected, also the companies themselves seem to have their problems. "For some reason, the natural conclusion to the life of a product seems to be a major challenge for many firms. Product and portfolio managers don't take product discontinuation seriously, nor do they typically make it an important part of product life cycle management decision options" (Heines, 2009, p. 619).

In early 80's, Avlonitis (1984) analyzed whether declining sales and profits, which are the main indications of the decline phase, are the only reasons to eliminate products. Or if other reasons can be found. He (ibid) was one of the first to investigate the elimination process in the UK engineering industry.

Avlonitis (1984) grouped them into 4 factors:

1. Financial considerations (Factor 1);

2. Resources released and external pressures considerations (Factor 2);

3. Marketing considerations (Factor 3);

4. Managerial (alternative opportunities) considerations (Factor 4).

Hart (1988) published 'The causes of Product Deletion in British Manufacturing Companies'. 
II: Avlonitis' 15 Circumstances of Product Elimination

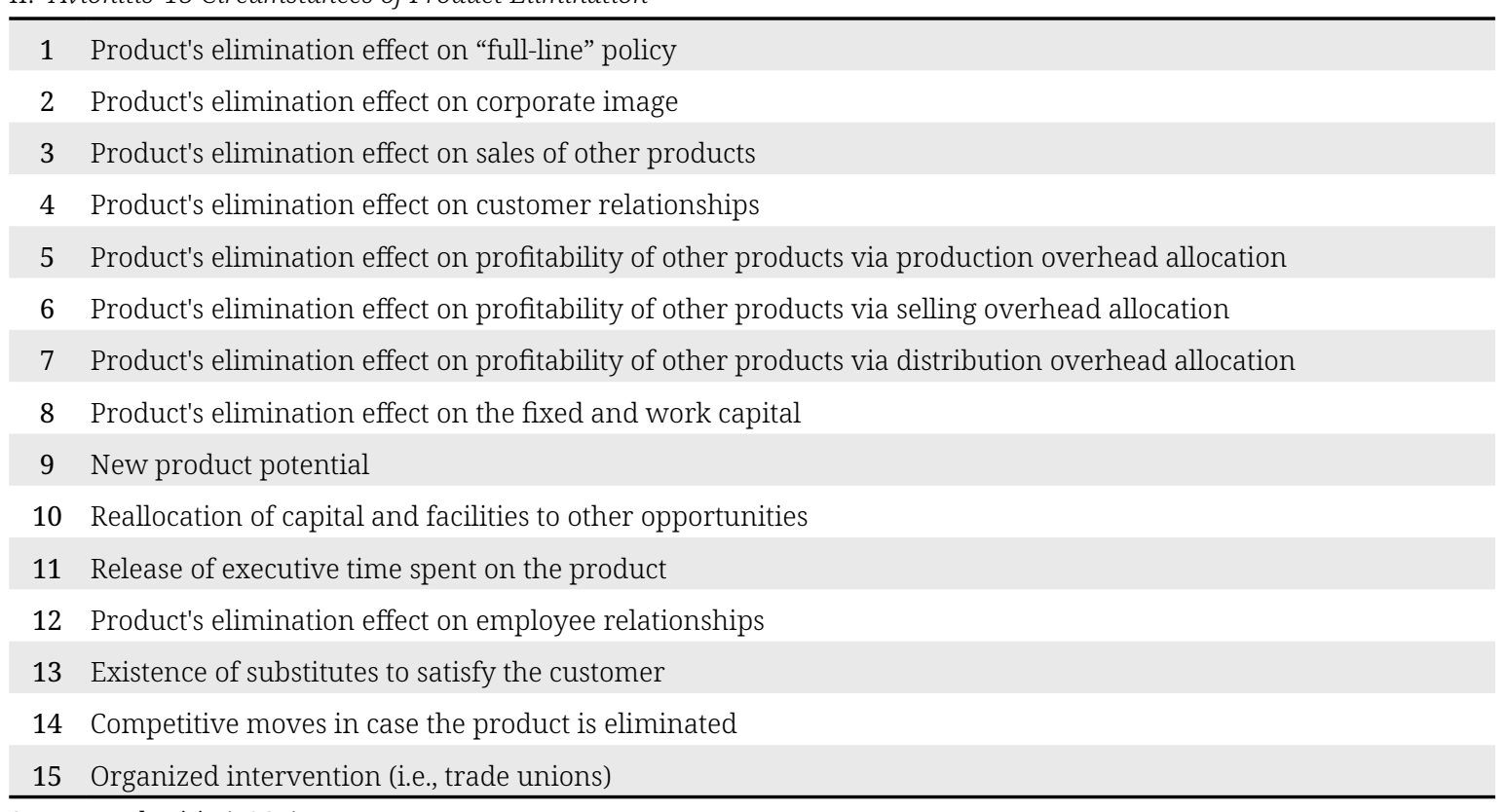

Source: Avlonitis (1984)

Her study focused on the British industry, both industrial $\mathrm{B} 2 \mathrm{~B}$ and $\mathrm{B} 2 \mathrm{C}$ business. Five industry sectors were selected for her study:

1. fast moving consumer goods,

2. industrial operating supplies,

3. consumer durables,

4. industrial components and

5. capital equipment.

III: Hart's 17 Circumstances of Product Elimination

\begin{aligned} & \hline 1 Government policies and regulations \\ & \hline 3 Operational problems \\ & \hline 4 Competitive activity \\ & 5 Development of a new product \\ & 6 Company resources required elsewhere \\ & \hline 7 Problems associated with raw materials/parts \\ & \hline 8 Variety reduction policy \\ & \hline 9 Decline in market potential \\ & \hline 10 Poor sales performance \\ & \hline 11 Poor profit performance \\ & \hline 12 Poor quality or design \\ & \hline 13 Poor fit with company capabilities or strategic plans \\ & \hline 14 Rationalization due to mergers and acquisitions \\ & \hline 15 Poor fit with company image \\ & \hline 16 Parent company decisions \\ & \hline 17 Change in exchange rate \\ & \hline\end{aligned}

Source: Hart (1988)
Her results were based on interviews with 31 companies as well as a mail survey to 922 companies (response rate 18\%, 166 surveys).

The most important circumstances were 'poor sales performance', 'poor profit performance' and 'decline in market potential'. But Hart (1988) noticed that none of the 17 factors scored a mean exceeding 3.8; therefore, she assumed that there is a relationship among the 17 circumstances. She used the principal component analysis and identified 6 groups of circumstances.

Hart (1988) analyzed whether there were significant differences among the 5 industry sectors (based on Miracle's 1965 product typology). Her result was that there are no significant differences concerning four of the deletion types: externally led, image/quality-led, resource-led and performanceled. However, endgame deletion seems to have greater importance for the capital equipment industrial sector. Hart included companies working in the following areas as the 'capital equipment sector industrial':

1. milling machines;

2. excavating equipment, cranes;

3. pumps;

4. elevators and escalators;

5. industrial saws;

6. electronic communication test measurement equipment.

Hart (1988, p. 341) explained in her paper that "in the capital equipment industry, the nature of the products and their high unit value means that the products have long working lives. Similarly, the heavy $R \& D$ burden of their development serves to prolong the product life cycle of the entire category of products". 
IV: Types of Product Elimination Decisions

\begin{tabular}{ll}
\hline \multicolumn{1}{c}{ Factor name } & \multicolumn{1}{c}{ Variables on factor } \\
\hline 1. Externally led deletion & Government policies and regulations \\
& Third-party decisions \\
& Rationalization due to mergers and acquisitions \\
& Parent company decisions and policies \\
\hline Change in exchange rate
\end{tabular}

Source: Hart (1988)

Mitchell et al. (1998) analyzed in their study whether the 17 circumstances Hart found in her study are also valid for the American industry. He found high correlation values between their and Hart's study. Mitchell and the team then used the factor analysis to group the 17 circumstances, like Hart did. They found a similar correlation and a great deal of consistency with the results obtained by Hart (1988). Mitchell et al. didn't split the examined US industries in sectors. Therefore, they could not examine if the 'endgame deletion factor' had higher importance for the capital equipment industry, like Hart analyzed. Both studies (Hart, 1988) and (Mitchell et al., 1998) isolated the factor 'Externally-led deletion' as the largest one.

Avlonitis (1990) investigated in his 'Project Dropstrat' the product elimination and the PLC concept. His study focused on the British manufacturing industry, he included both B2C and B2B companies. He found that there were different circumstances why companies eliminate products and that these circumstances differed with the stage of the PLC. Avlonitis' data showed the elimination process depends on the stage of the PLC. In the introduction stage a product is mainly eliminated due to operational problems and low sales numbers. At the growth stage a product will be phased out from the market due to poor quality or design problems as well as due to operational problems. In the mature phase products are eliminated because of increasing competition and decline in market potential. These two reasons are also valid in the decline phase, additionally two more precipitating circumstances which are associated with this particular stage, namely, 'development of a variety reduction policy' and 'poor sales performance', are likely to initiate the product elimination process (Avlonitis, 1990, p. 66).

Avlonitis (1987) noted that a separate study for consumer and industrial products would be necessary and that his study was only the beginning, it needed to be validated and replicated. Later studies of Avlonitis et al. (2000) or other researchers (Argouslidis and McLean, 2003; Argouslidis and Baltas, 2007; Gounaris et al., 2006; Harness and Harness, 2004; Harness and Harness, 2012; Harness and Harness, 2007) focused on the finance sectors, service (Somosi and Kolos, 2017), B2C goods (Argouslidis et al., 2014; Muir and Reynolds, 2011), and human resource sector (Wagner et al., 2017).

\section{MATERIALS AND METHODS}

The objective of this paper is to analyze the product deletion process of German mechanical engineering companies. Especially whether the product deletion reasons (Avlonitis, 1984; Hart, 
1988; Mitchell et al., 1998) identified for industrial UK and US companies are valid for German companies. The paper will analyze if all products which reach the decline stage are typically eliminated, or whether they stay long term in the product portfolio. It will be analyzed who is involved in the product elimination process and whether companies develop a formal process to eliminate products from their product portfolios, or if there is a need for such.

The study was based on an empirical analysis based on 102 interviews with German mechanical engineering companies' representatives with a structured questionnaire.

In the literature different research methods can be found. The quantitative research method approach with personal interviews and structured questions are used if existing research studies will be replicated and to compare the results with statistical methods (Flick et al., 2011).

The questionnaire was divided into 3 sections; the first section collected general information about an analyzed company and an interviewed person. The study was done without noting the name of the company, nor the interviewed person.

The second section of the questionnaire covered the product elimination in general and referred to specific elimination cases the interviewed person was involved in in the last three years. In which stage of the product life cycle the product was and if each product which entered the decline stage was eliminated. If not, why it stayed longer/permanently in the product portfolio. Who was involved in the elimination process, who was the decision maker and whether the company had a formal process to eliminate products? Furthermore, it was analyzed if the company faced problems during the process.

The third part started with the importance ranking of the factors Avlonitis (1984) and Hart (1988) identified in their studies. In the end, there was an open question to analyze if the German mechanical engineering companies had additional elimination reasons which were not included in Avlonitis' and Hart's list of circumstances.

The first contact and several interviews were conducted during the international trade fair 'Hannover Messe' (April 23-27, 2018) where many German engineering companies with international

V: Distribution of the Interviewed Persons over the Branches

\begin{tabular}{lcc}
\hline Branch of the industry & Frequency & $\begin{array}{c}\text { Relative frequency } \\
\text { (in \%) }\end{array}$ \\
\hline Automation & 18 & 18 \\
Power Transmission & 18 & 18 \\
Industrial Supply & 35 & 34 \\
Mechanical Engineering & 31 & 30 \\
\hline Total & 102 & 100 \\
\hline
\end{tabular}

Source: Interviews, April 2018, $n=102$ focus participated with their own booth. It is the world's leading exhibition for industrial technology innovations. In order to ensure that interviewed persons had the necessary knowledge and experience to discuss the product elimination process the focus was mainly on product managers and on all other company employees who were involved in the past three years with the product elimination process in their company. Some of the persons interviewed needed more time (either they were too busy during the exhibition or they needed to look up elimination cases in their documentation, or the right contact person with experience was at the moment not available during the exhibition); thus, an arrangement was set to interview them after the exhibition via skype and email.

The interviewed persons were working in the following branches (Tab. V).

The annual sales turnover question was not answered by the interviewed persons, but they gave the following split regarding the size of the company (measured in number of employees) - see Tab. VI, and number of products in their portfolios - see Tab. VII.

The respondents rated the relative importance of each precipitating circumstance originally identified by Hart (Hart, 1988) on their particular product elimination decision of reference on a 5-point Likert scale ( 1 = of little or no importance to 5 = extremely important). Hart reported the relative frequency of occurrence in her study. The same is done here to compare both the results of both studies. The data is presented in descending order of importance.

VI: Number of Employees of the Interviewed Companies

\begin{tabular}{lcc}
\hline Number of employees & Frequency & $\begin{array}{c}\text { Relative frequency } \\
\text { (in \%) }\end{array}$ \\
\hline $1-100$ & 14 & 14 \\
$101-500$ & 49 & 48 \\
$501-4999$ & 35 & 34 \\
$5000+$ & 4 & 4 \\
\hline Total & 102 & 100 \\
\hline
\end{tabular}

Source: Interviews, April 2018, $n=102$

VII: Number of Products in the Product Portfolio of the Interviewed Companies

\begin{tabular}{lcc}
\hline $\begin{array}{c}\text { Number of products } \\
\text { in product portfolio }\end{array}$ & Frequency & $\begin{array}{c}\text { Relative frequency } \\
\text { (in \%) }\end{array}$ \\
\hline $10-50$ & 48 & 47 \\
$51-100$ & 20 & 20 \\
$101-200$ & 22 & 22 \\
$201-500$ & 9 & 8 \\
$501+$ & 3 & 3 \\
\hline Total & 102 & 100 \\
\hline
\end{tabular}

Source: Interviews, April 2018, n = 102 


\section{RESULTS}

\section{Hart's Product Elimination Factors}

The variable with the greatest influences for product elimination shows the highest relative influence. Among German mechanical engineering companies, poor profit and sales performance as well as development of a new product and decline of market potential were identified as the reasons with the major influence for product elimination decisions.

To compare these results with the previous studies (Hart, 1988) and (Mitchell et al., 1998) the Spearman's rank-order correlation coefficient was used. The Spearman's rank-order correlation coefficient analyses the correlation of the ranks of the values between two sets (Daniel, 1992). Mitchell et al. (1998) has used this correlation coefficient to compare his results with Hart (1988). The calculations for the Spearman's value can be found in Tab. IX and Tab. X. The $n$ for Hart's analysis equals 17.

The Spearman's rank order correlation value shows that the ranks of the variables of the studies have an extremely high positive correlation. The correlation value to (Mitchell et al., 1998) results shows even a higher value than to the original study (Hart, 1988).

The high correlation value indicates a big consistency between the results of all three studies.
That displays that the variables found originally by Hart (1988) are also valid not only for the US, but also for German engineer companies. The variables used to make a product elimination decision are very similar between in the different countries UK, US and Germany analyzed.

Hart (1988) grouped the 17 factors into 6 groups (see Tab. IV), using the principal component analysis. The same was done with the new data to extract and compare the most important independent factors. The Kaiser-Meyer-Olkin measure of sampling adequacy was 0.461, which is a relatively low factor. But for comparison reasons the principal component analysis was conducted even with this low factor. The Bartlett's test of sphericity was significant ( $p<0.0051$ ), indicating that correlations between items were sufficiently large for performing a principal component analysis (Tab. XI).

The correlations and variable loading between the 17 factors show a different result than Hart's study (Tab. XII).

In Hart's study are only the variable loadings listed of the factors but not the complete list of results, so that further analysis with the data is not advisable. Maybe the Kaiser-Meyer-Olkin value was even at Hart's study low and it would have been better to use a different statistical calculation tool instead of the principal component analysis, or the companies see nowadays a different correlation between these factors.

VIII: Relative Importance of Hart's Variables (Hart, 1988) of the Interviewed Companies

\begin{tabular}{|llll|}
\hline Variable & Mean Value & Standard Deviation \\
\hline A11 & Poor profit performance & 4.01 & 0.75 \\
A10 & Poor sales performance & 3.94 & 0.76 \\
\hline A5 & Development of a new product & 3.43 & 0.84 \\
\hline A9 & Decline in market potential & 3.39 & 0.79 \\
\hline A4 & Competitive activity & 3.02 & 0.80 \\
\hline A6 & Company resources required elsewhere & 0.87 \\
\hline A13 & Poor fit with company capabilities or strategic plans & 2.98 & 0.85 \\
\hline A12 & Poor quality or design & 2.95 & 0.83 \\
\hline A2 & Operational problem & 2.94 & 0.86 \\
\hline A7 & Problems associated with raw materials and/or parts & 2.63 & 0.65 \\
\hline A8 & Variety reduction policy & 2.61 & 0.68 \\
\hline A3 & Third party decision (i.e. major customer exits market) & 2.44 & 0.80 \\
\hline A1 & Government policies and regulations & 2.33 & 0.95 \\
\hline A15 & Poor fit with company image & 2.21 & 0.88 \\
\hline A14 & Rationalization due to mergers and acquisitions & 2.03 & 0.72 \\
\hline A16 & Parent company decision and policies & 1.68 & 0.64 \\
\hline A17 & Change in exchange rates & 1.58 & 0.47 \\
\hline
\end{tabular}

Source: Interviews, April 2018, $n=102$ 
IX: Spearman's Rank-Order Correlation Coefficient (Hart's Study)

\begin{tabular}{llcccc}
\hline Variable & Rank today & Rank Hart & $\mathrm{d}$ & $\mathrm{d}^{2}$ \\
\hline A1 & Government policies and regulations & 13 & 15.5 & -2.50 & 6.25 \\
A2 & Operational problem & 9 & 5.5 & 3.50 & 12.25 \\
A3 & Third party decision (i.e. major customer exits market) & 12 & 15.5 & -3.50 & 12.25 \\
A4 & Competitive activity & 5 & 5.5 & -0.50 & 0.25 \\
A5 & Development of a new product & 3 & 4 & -1.00 & 1 \\
A6 & Company resources required elsewhere & 6 & 10 & -4.00 & 16 \\
A7 & Problems associated with raw materials and/or parts & 10 & 13 & -3.00 & 9 \\
A8 & Variety reduction policy & 11 & 9 & 2.00 & 4 \\
A9 & Decline in market potential & 4 & 3 & 1.00 & 1 \\
A10 & Poor sales performance & 2 & 2 & 0.00 & 0.00 \\
A11 & Poor profit performance & 1 & 1 & 0.00 & 0.00 \\
A12 & Poor quality or design & 8 & 8 & 0.00 & 0.00 \\
A13 & Poor fit with company capabilities or strategic plans & 7 & 7 & 0.00 & 0.00 \\
A14 & Rationalization due to mergers and acquisitions & 15 & 17 & -2.00 & 4.00 \\
A15 & Poor fit with company image & 14 & 11.5 & 2.50 & 6.25 \\
A16 & Parent company decision and policies & 16 & 14 & 2.00 & 4 \\
A17 & Change in exchange rates & 17 & 11.5 & 5.50 & 30.25 \\
\hline & & & Sum & 106.5 \\
\hline S0ure: & & & & \\
\hline
\end{tabular}

Source: Interviews, April 2018, n = 102 and Hart (1988)

Spearman's value $=1-\frac{6\left(\text { Sum d }^{2}\right)}{n\left(n^{2}-1\right)}=1-\frac{6(106.5)}{17(288)}=0.869 \quad$ (1) $\quad$ Spearman's value $=1-\frac{6\left(\text { Sum d } d^{2}\right)}{n\left(n^{2}-1\right)}=1-\frac{6(8)}{17(288)}=0.991$

X: Spearman's Rank-Order Correlation Coefficient (Mitchell et al. study)

\begin{tabular}{llcccc}
\hline Variable & Rank today & Rank Mitchell & $\mathrm{d}$ & $\mathrm{d}^{2}$ \\
\hline A1 & Government policies and regulations & 13 & 13 & 0.00 & 0.00 \\
A2 & Operational problem & 9 & 8 & 1.00 & 1.00 \\
A3 & Third party decision (i.e. major customer exits market) & 12 & 12 & 0.00 & 0.00 \\
A4 & Competitive activity & 5 & 5 & 0.00 & 0.00 \\
A5 & Development of a new product & 3 & 4 & -1.00 & 1.00 \\
A6 & Company resources required elsewhere & 6 & 7 & -1.00 & 1.00 \\
A7 & Problems associated with raw materials and/or parts & 10 & 10 & 0.00 & 0.00 \\
A8 & Variety reduction policy & 11 & 11 & 0.00 & 0.00 \\
A9 & Decline in market potential & 4 & 3 & 1.00 & 1.00 \\
A10 & Poor sales performance & 2 & 1 & 1.00 & 1.00 \\
A11 & Poor profit performance & 1 & 2 & -1.00 & 1.00 \\
A12 & Poor quality or design & 8 & 9 & -1.00 & 1.00 \\
A13 & Poor fit with company capabilities or strategic plans & 7 & 6 & 1.00 & 1.00 \\
A14 & Rationalization due to mergers and acquisitions & 15 & 15 & 0.00 & 0.00 \\
A15 & Poor fit with company image & 14 & 14 & 0.00 & 0.00 \\
A16 & Parent company decision and policies & 16 & 16 & 0.00 & 0.00 \\
A17 & Change in exchange rates & 17 & 17 & 0.00 & 0.00 \\
\hline & & & $5 u m$ & 8.00 \\
\hline Source & & & & \\
\hline
\end{tabular}

Source: Interviews, April 2018, $\mathrm{n}=102$ and Mitchell et al. (1998) 
XI: Principal Component Analysis

\begin{tabular}{|c|c|c|c|c|c|c|}
\hline & \multicolumn{6}{|c|}{ Component } \\
\hline & 1 & 2 & 3 & 4 & 5 & 6 \\
\hline Government policies and regulations & -0.334 & 0.116 & -0.037 & 0.158 & 0.521 & -0.200 \\
\hline Operational problem & -0.296 & -0.200 & -0.301 & 0.309 & 0.300 & 0.419 \\
\hline Third party decision (i.e. major customer exits market) & 0.665 & -0.059 & 0.046 & 0.485 & 0.052 & 0.172 \\
\hline Competitive activity & 0.017 & 0.304 & -0.015 & 0.443 & 0.379 & -0.302 \\
\hline Development of a new product & -0.082 & 0.506 & -0.396 & -0.392 & -0.070 & -0.032 \\
\hline Company resources required elsewhere & -0.249 & 0.495 & 0.115 & -0.039 & 0.207 & 0.333 \\
\hline Problems associated with raw materials and/or parts & 0.065 & 0.091 & -0.522 & 0.071 & -0.439 & 0.179 \\
\hline Variety reduction policy & 0.715 & 0.162 & 0.089 & 0.085 & 0.243 & 0.153 \\
\hline Decline in market potential & 0.002 & 0.546 & 0.218 & -0.044 & -0.097 & 0.258 \\
\hline Poor sales performance & -0.194 & 0.277 & 0.087 & 0.454 & -0.350 & -0.276 \\
\hline Poor profit performance & 0.238 & 0.108 & 0.063 & 0.234 & -0.348 & -0.332 \\
\hline Poor quality or design & -0.368 & 0.411 & 0.391 & 0.062 & -0.223 & 0.228 \\
\hline Poor fit with company capabilities or strategic plans & 0.222 & 0.556 & 0.100 & -0.040 & 0.197 & -0.029 \\
\hline Rationalization due to mergers and acquisitions & -0.281 & -0.221 & 0.557 & 0.320 & -0.229 & 0.312 \\
\hline Poor fit with company image & 0.511 & -0.033 & 0.026 & -0.155 & -0.017 & 0.399 \\
\hline Parent company decision and policies & -0.217 & -0.299 & 0.388 & -0.240 & 0.202 & 0.013 \\
\hline Change in exchange rates & 0.334 & 0.004 & 0.553 & -0.334 & 0.001 & -0.274 \\
\hline
\end{tabular}

Source: Interviews, April 2018, $n=102$

XII: New Types of Product Elimination Decisions

\begin{tabular}{|c|c|}
\hline Factor & Variables on factor \\
\hline \multirow{2}{*}{1.} & Government policies and regulations \\
\hline & Poor profit performance \\
\hline 2. & Operational problem \\
\hline \multirow{3}{*}{3.} & $\begin{array}{l}\text { Third party decision (i.e. major customer exits } \\
\text { market) }\end{array}$ \\
\hline & Variety reduction policy \\
\hline & Poor fit with company image \\
\hline \multirow{5}{*}{4.} & Development of a new product \\
\hline & Company resources required elsewhere \\
\hline & Decline in market potential \\
\hline & Poor quality or design \\
\hline & Poor fit with company capabilities or strategic plans \\
\hline \multirow{2}{*}{5.} & Competitive activity \\
\hline & Poor sales performance \\
\hline \multirow{4}{*}{6.} & Problems associated with raw materials and/or parts \\
\hline & Rationalization due to mergers and acquisitions \\
\hline & Parent company decision and policies \\
\hline & Change in exchange rates \\
\hline
\end{tabular}

Source: Interviews, April 2018, $n=102$

\section{Avlonitis' Product Elimination Factors}

In the study from 1984 Avlonitis (1984) identified fifteen product elimination factors. The respondents in this study rated the relative importance of each factor on their particular product elimination decision of reference on a 5-point Likert scale (from 1 = of little or no importance, to 5 = extremely important). Avlonitis reported the relative frequency of occurrence in his study. The same is done here to compare the results of both studies. The data is presented in Tab. XIII in descending order of importance. The $n$ for Avlonitis' analysis equals 15.

Like the results of (Avlonitis, 1984) and (Mitchell et al., 1998) the interviewed German engineering companies rated the relative importance of external relationship factors as more important than internal factors, e.g. the relationship to employees or the corporate image.

The Spearman's rank order correlation coefficient was used again to compare the ranking of Avlonitis' factors (Avlonitis, 1984) in the studies by Mitchell et al. (1998) and the new German study. The calculations for the Spearman's value can be found in Tab. XIV and Tab. XV.

The Spearman's rank order correlation value shows that the ranks of the product elimination variables of the studies have a high positive correlation. The high correlation value indicates a big consistency between the results of all three studies. 
XIII: Relative Importance of Avlonitis' Factors of the Interviewed Companies

\begin{tabular}{|c|c|c|c|}
\hline \multicolumn{2}{|c|}{ Variable } & \multicolumn{2}{|c|}{$\begin{array}{l}\text { Mean Standard } \\
\text { Value Deviation }\end{array}$} \\
\hline B3 & Product's elimination effect on customer relationships & 3.56 & 0.64 \\
\hline B8 & Existence of substitutes to satisfy the customer & 3.34 & 0.75 \\
\hline B1 & New product potential & 3.32 & 0.75 \\
\hline $\mathrm{B} 2$ & Product's elimination effect on sales of other products & 3.30 & 0.73 \\
\hline B5 & Reallocation of capital and facilities to other opportunities & 3.14 & 0.72 \\
\hline B4 & $\begin{array}{l}\text { Product's elimination effect on profitability of other products via production overhead } \\
\text { allocation }\end{array}$ & 2.99 & 0.83 \\
\hline B6 & Product's elimination effect on 'full-line' policy & 2.77 & 0.64 \\
\hline B12 & Competitive moves in case the product is eliminated & 2.48 & 0.66 \\
\hline B10 & Product's elimination effect on profitability of other products via selling overhead allocation & 2.37 & 0.58 \\
\hline B9 & Product's elimination effect on the fixed and work capital & 2.36 & 0.61 \\
\hline B13 & Product's elimination effect on profitability of other products via distribution overhead allocation & 2.28 & 0.69 \\
\hline B11 & Product's elimination effect on corporate image & 2.10 & 0.76 \\
\hline B7 & Release of executive time spent on the product & 1.81 & 0.71 \\
\hline B14 & Product's elimination effect on employee relationships & 1.63 & 0.64 \\
\hline B15 & Organized intervention (i.e. trade unions) & 1.18 & 0.41 \\
\hline
\end{tabular}

Source: Interviews, April 2018, n = 102 and Avlonitis (1984)

XIV: Spearman's Rank-Order Correlation Coefficient of Avlonitis' Factors (Hart Study)

\begin{tabular}{|c|c|c|c|c|c|}
\hline \multicolumn{2}{|c|}{ Variable } & \multirow{2}{*}{$\frac{\text { Rank today }}{3}$} & \multirow{2}{*}{$\frac{\text { Rank Hart }}{1}$} & \multirow{2}{*}{$\frac{d}{2}$} & \multirow{2}{*}{$\frac{d^{2}}{4}$} \\
\hline B1 & New product potential & & & & \\
\hline B2 & Product's elimination effect on sales of other products & 4 & 2.5 & 1.5 & 2.25 \\
\hline B3 & Product's elimination effect on customer relationships & 1 & 2.5 & -1.5 & 2.25 \\
\hline $\mathrm{B} 4$ & $\begin{array}{l}\text { Product's elimination effect on profitability of other } \\
\text { products via production overhead allocation }\end{array}$ & 6 & 4 & 2 & 4 \\
\hline B5 & $\begin{array}{l}\text { Reallocation of capital and facilities to other } \\
\text { opportunities }\end{array}$ & 5 & 5.5 & -0.5 & 0.25 \\
\hline $\mathrm{B} 6$ & Product's elimination effect on 'full-line' policy & 7 & 6 & 1 & 1 \\
\hline B7 & Release of executive time spent on the product & 13 & 7.5 & 5.5 & 30.25 \\
\hline B8 & Existence of substitutes to satisfy the customer & 2 & 7.5 & -5.5 & 30.25 \\
\hline B9 & Product's elimination effect on the fixed and work capital & 10 & 10 & 0 & 0 \\
\hline $\mathrm{B} 10$ & $\begin{array}{l}\text { Product's elimination effect on profitability of other } \\
\text { products via selling overhead allocation }\end{array}$ & 9 & 10 & -1 & 1 \\
\hline B11 & Product's elimination effect on corporate image & 12 & 10 & 2 & 4 \\
\hline B12 & Competitive moves in case the product is eliminated & 8 & 12.5 & -4.5 & 20.25 \\
\hline B13 & $\begin{array}{l}\text { Product's elimination effect on profitability of other } \\
\text { products via distribution overhead allocation }\end{array}$ & 11 & 12.5 & -1.5 & 2.25 \\
\hline B14 & Product's elimination effect on employee relationships & 14 & 14 & 0 & 0 \\
\hline \multirow[t]{2}{*}{ B15 } & Organized intervention (i.e. trade unions) & 15 & 15 & 0 & 0 \\
\hline & & & & Sum & 101.75 \\
\hline
\end{tabular}

Source: Interviews, April 2018, n = 102 and Hart (1988)

Spearman's value $=1-\frac{6\left(\text { Sum d }^{2}\right)}{n\left(n^{2}-1\right)}=1-\frac{6(101.75)}{15(224)}=0.818$ 
XV: Spearman's Rank-Order Correlation Coefficient of Avlonitis' Factors (Mitchell et al. study)

\begin{tabular}{|c|c|c|c|c|c|}
\hline \multicolumn{2}{|c|}{ Variable } & \multirow{2}{*}{$\begin{array}{c}\text { Rank today } \\
3\end{array}$} & \multirow{2}{*}{$\frac{\text { Rank Mitchell }}{3}$} & \multirow{2}{*}{$\frac{\mathrm{d}}{0}$} & \multirow{2}{*}{$\frac{\mathrm{d}^{2}}{0}$} \\
\hline B1 & New product potential & & & & \\
\hline B2 & Product's elimination effect on sales of other products & 4 & 4 & 0 & 0 \\
\hline B3 & Product's elimination effect on customer relationships & 1 & 1 & 0 & 0 \\
\hline B4 & $\begin{array}{l}\text { Product's elimination effect on profitability of other } \\
\text { products via production overhead allocation }\end{array}$ & 6 & 5 & 1 & 1 \\
\hline B5 & $\begin{array}{l}\text { Reallocation of capital and facilities to other } \\
\text { opportunities }\end{array}$ & 5 & 6 & -1 & 1 \\
\hline B6 & Product's elimination effect on "full-line" policy & 7 & 7 & 0 & 0 \\
\hline B7 & Release of executive time spent on the product & 13 & 13 & 0 & 0 \\
\hline B8 & Existence of substitutes to satisfy the customer & 2 & 2 & 0 & 0 \\
\hline B9 & $\begin{array}{l}\text { Product's elimination effect on the fixed and work } \\
\text { capital }\end{array}$ & 10 & 10 & 0 & 0 \\
\hline B10 & $\begin{array}{l}\text { Product's elimination effect on profitability of other } \\
\text { products via selling overhead allocation }\end{array}$ & 9 & 9 & 0 & 0 \\
\hline B11 & Product's elimination effect on corporate image & 12 & 11 & 1 & 1 \\
\hline B12 & Competitive moves in case the product is eliminated & 8 & 12 & -4 & 16 \\
\hline B13 & $\begin{array}{l}\text { Product's elimination effect on profitability of other } \\
\text { products via distribution overhead allocation }\end{array}$ & 11 & 8 & 3 & 9 \\
\hline B14 & Product's elimination effect on employee relationships & 14 & 14 & 0 & 0 \\
\hline \multirow[t]{2}{*}{ B15 } & Organized intervention (i.e., trade unions) & 15 & 15 & 0 & 0 \\
\hline & & & & Sum & 28 \\
\hline
\end{tabular}

Source: Interviews, April 2018, n = 102 and Mitchell et al. (1998)

Spearman's value $=1-\frac{6\left(\text { Sum }^{2}\right)}{n\left(n^{2}-1\right)}=1-\frac{6(28)}{15(224)}=0.950$

That displays that the variables found originally by Avlonitis (1984) are also valid not only for the US, but also for German engineer companies. The variables used to make a product elimination decision are very similar between in the different countries UK, US and Germany analyzed.

\section{DISCUSSION AND CONCLUSION}

The product elimination decision process in German mechanical engineering companies was compared with data from UK and US studies. The relative importance of the factors analysed by Avlonitis (1984) and Hart (1988) in the UK are highly correlating with the data in the US and Germany. The studies in UK and US were carried out in the 80's, regardless this significant time difference between those studies and the German study the results show that problems that lead industrial companies to product phase out decisions as well as the data companies are using in making that decision are very much the same in UK, US and Germany. Which is somehow not surprising because the PLC model has not lost the relevance and is still valid. Some factors like B8 "Existence of substitutes to satisfy the customer", got a different ranking (Tab. XIV), it looks like the threat of substitutes is today much more important than it was in the past. It seems like the international availability of products and, therefore, competition is now much more intense than it was during the 80's when Avlonitis and Hart conducted their studies. Which also explains the different ranking of B12 "Competitive moves in case the product is eliminated" (Tab. XIV).

The different results of the principal component analysis should be analysed further perhaps with a second study in Germany in a different industry sector or in a different country, to compare in detail the results and to have more data for analysing.

In the end of the questionnaire there was an open question to analyze whether the German mechanical engineering companies had additional elimination reasons which were not included in Avlonitis' and Hart's list of circumstances, none of the questioned German mechanical engineering companies provided an additional reason. 
Decreasing sales figures, low market share and shrinking profit are the main indicators of the decline phase in the PLC and those factors show the highest relative importance ranking in the product elimination process. But they are not the only factors which trigger industrial engineering companies to eliminate products. Internal factors like low quality/design, cross profitability effects in operation or operational problems are also reasons to start the elimination process.

In the next step additional factor analysis will be carried out to analyse the data in more depth.

\section{REFERENCES}

ARGOUSLIDIS, P. C. and MCLEAN, F. 2003. Service elimination decision-making, The identification of financial services as candidates for elimination. European Journal of Marketing, 38(11/12): 1355-1381.

ARGOUSLIDIS, P. C. and BALTAS, G. 2007. Structure in product line management: The role of formalization in service elimination decisions. Journal of the Academy of Marketing Science, 35: 475-491.

ARGOUSLIDIS, P., BALTAS, G. and MAVROMMATIS, A. 2014. Outcomes of decision speed: An empirical study in product elimination decision-making processes. European Journal of Marketing, 48(5/6): 982-1008.

AVLONITIS, G. J. 1984. Industrial Product Elimination: Major Factors to Consider. Industrial Marketing Management, 13: 77-85.

AVLONITIS, G. J. 1987. Linking different types of product elimination decisions to their performance outcome: 'Project Dropstrat'. Journal of Research in Marketing, 4: 43-57.

AVLONITIS, G. J. 1990. 'Project Dropstrat': Product Elimination and the Product Life Cycle Concept. European Journal of Marketing, 24(9): 55-67.

AVLONITIS, G. J., HART, S. and NIIKOLAOS, X. T. 2000. An analysis of product deletion scenarios. Journal of Product Innovation Management, 17: 41-56.

AYAL, I. 1981. International Product Life Cycle: A Reassessment and Product Policy Implications. Journal of Marketing, 45(4): 91-96.

DANIEL, W. M. 1992. Applied Nonparametric Statistics. $2^{\text {nd }}$ Edition. Boston, MA: PWS-Kent Publishing Company.

FISCHER, M. 2001. Produktlebenszyklus und Wettbewerbsdynamik: Grundlagen für die ökonomische Bewertung von Markteintrittsstrategien. Betriebswirtschaftlicher Verlag Dr. Th. Gabler.

FLICK, U., KARDORFF, E. V., KEUPP, H., ROSENSTEIL, L. V. and WOLFF, S. 2011. Handbuch qualitative Sozialforschung. Grundlagen, Konzepte, Methoden und Anwendungen. Weinheim: Beltz.

GOUNARIS, S. P., AVLONITIS, G. J. and PAPASTATHOPOULOU, P. G. 2006. Uncovering the keys to successful service elimination: 'Project ServDrop'. Journal of Services Marketing, 20(1): 24-36.

HAINES, S. 2009. The Product Manager's Desk Reference. $2^{\text {nd }}$ Edition. Mc Graw Hill Education.

HART, S. 1988. The causes of product deletion in British manufacturing companies. Journal of Marketing Management, 3(3): 328-343.

HARNESS, D. and HARNESS, T. 2004. The New Customer Relationship Management Tool - Product Elimination? The Service Industries Journal, 24(2): 67-80.

HARNESS, D. and HARNESS, T. 2012. Can Product Elimination support post-downsizing success aspirations? Journal of General Management, 38(2): 39-60.

HARNESS, T. and HARNESS, D. 2007. The stages of financial services product elimination. Journal of Financial Services Marketing, 12(3): 197-207.

HERRMANN, A., HUBER, F. and FISCHER, M. 2000. Produktelimination auf der Basis des Fuzzy-SetAnsatzes. Thexis, 17(2): 28-33.

KOMNINOS, I., MILOSSIS, D. and KOMNINOS, N. 2002. Product Life Cycle Management. URENIO Urban and Regional Innovation Research Unit, Faculty of Engineering, Aristotle University of Thessaloniki. Available at: https://www.urenio.org/tools/en/Product_Life_Cycle_Management.pdf [Accessed: 2019, February 20].

KUSS, A., TOMCZAK, T. and REINECKE, S. 2007. Marketingplanung, Einführung in die marktorientierte Unternehmens- und Geschäftsfeldplanung. $5^{\text {th }}$ Edition. Wiesbaden: Betriebswirtschaftlicher Verlag Dr. Th. Gabler.

LENNERTZ, D., 2006. Produktmanagement, Frankfurt am Main: F.A.Z. Institut fuer Management-, Markt- und Medieninformatik GmbH.

MEFFERT, H., BURMANN, C. and KIRCHGEORG, M. 2008. Marketing - Grundlagen marktorientierter Unternehmensführung. 10 ${ }^{\text {th }}$ Edition. Wiesbaden: Betriebswirtschaftlicher Verlag Dr. Th. Gabler.

MITCHELL, M. A., TAYLOR, R. D. and TANYEL, F. 1998. Product Elimination Decisions: A comparison of American and British Manufacturing firms. International Journal of Commerce and Management, 8(1): 8-27. 
MUIR, J. and REYNOLDS, N. 2011. Product deletion: a critical overview and empirical insight into this process. Journal of General Management, 37(1): 5-30.

SCHMALEN, H. and PECHTL, H. 2013. Grundlagen und Probleme der Betriebswirtschaft. SchäfferPoeschel Verlag für Wirtschaft, Steuern, Recht GmbH.

SOMOSI, Á. and KOLOS, K. 2017. The role of economic and psychological costs in service elimination. Vezetéstudomány/Budapest Management Review, 48(5): 14-23.

TERZI, S., BOURAS, A., DUTTA, D., GARETTI, M. and KIRITSIS, D. 2010. Product lifecycle management - from its history to its new role. International Journal Product Lifecycle Management, 4(4): 360-389.

WAGNER, R., ABDELKAFI, N. and BLECKER, T. 2017. Exploration of the product phase-out process in manufacturing firms: A human factor perspective. Business Process Management Journal, 23(5): 1000-1017.

Contact information

Christina Astrid Wiltrud Bauer: Christina_bauer_@gmx.de Jana Turčínková: jana.turcinkova@mendelu.cz 